\title{
APPLICATION OF RESPONSE SURFACE METHODOLOGY FOR OPTIMIZING FUEL CONSUMPTION OF A DISK PLOW IN LOAMY SAND SOIL
}

\author{
ABOUKARIMA, A. M. \\ Agricultural Engineering Research Institute, ARC, Dokki, Giza
}

(Manuscript received 20 September 2016)

\begin{abstract}
D isk plow is considered to be effective tool used for cutting, pulverizing, elevating and inverting furrow slices as primary tillage. Tillage is the most fuel demanding in crop production. Thus, appropriate management and use of modern management techniques are essential to reduce fuel consumption. Thus, the purpose of this study was to determine the optimum conditions for the fuel consumption of a disk plow operating in loamy sand soil using Response Surface Methodology. Initially, values of fuel consumption were produced from field experiments. The fuel consumption data was collected at different factors of plowing speed, plowing depth, disk angle, tilt angle and soil moisture content according to the experimental design which was recommended by Response Surface Methodology of MINITAB software version 16. The coefficient of determination $\left(R^{2}\right)$ was $94.967 \%$ meaning that the experimental data were acceptable. It was found that the lowest fuel consumption could be optimized at plowing speed of $3.24 \mathrm{~km} / \mathrm{h}$, plowing depth of $10.03 \mathrm{~cm}$, disk angle of $40^{\circ}$, tilt angle of $15^{\circ}$ and soil moisture content of $6.06 \% \mathrm{db}$. The verification value of fuel consumption at the optimum conditions which was determined by the experimental work was $3.25 \mathrm{lit} / \mathrm{h}$. Since the difference between the verification and predicted values was less than $5 \%$, therefore, the optimum conditions for the fuel consumption predicted by MINITAB software Version 16 could be accepted. The model can be used to estimate fuel consumption of a disk plow operating in loamy sand soil within the studied range of the investigated factors.
\end{abstract}

\section{INTRODUCTION}

Soil tillage is the most expensive and complicated operation, fuel demanding and time consuming (Zugec et al., 2000) in crop production. Disk plows are well adapted for plowing in extremely hard soil; for cutting, pulverizing, elevating and inverting furrow slices in primary as well as in secondary tillage. However, during soil tillage there are multiple independent factors affecting the fuel consumption of a plow such as speed of operation, area of cut, plowing depth, type of soil, skills of operator, soil moisture content and type of the plow (Leghari et al., 2016). Consequently, appropriate management and use of modern management techniques are essential to 
apply an optimum method which can show the main and interaction effect of all the factors on the fuel consumption of such plow.

Response surface methodology has been reported to be an effective tool for optimization of a process when the independent factors have a combined effect on the desired response (Koocheki et al., 2009). It is a collection of a mathematical and statistical technique that can be useful for modeling and analysing situations in which a response of interest is influenced by several factors and the objective is to optimize this response (Pishgar-Komleh et al., 2012). Although several studies were done by applying response surface methodology for optimization, there was no related research to the current study. However, Mamkag (2002) found that forward speed, disk and tilt angles had clear effect on fuel consumption of a disk plow. Osman et al. (2011) indicated that tilt angle of the mounted disk plow had strong effect on performance of a disk plow. Abdalla et al. (2014) reported that angles of a disk plow (tilt and disk) affect fuel consumption of a tractor. The disk angles were $43^{\circ}$ and $45^{\circ}$ and the tilt angles were $15^{\circ}, 20^{\circ}$ and $25^{\circ}$.

Since soil tillage is one of the main greatest energy consumers (Namdari et al., 2011) and it is the most expensive and complicated operation, fuel demanding and time consuming (Zugec et al., 2000) in crop production. Thus the purpose of this study was to determine the optimum conditions for reducing fuel consumption of a disk plow operating in loamy sand soil using Response Surface Methodology.

\section{MATREIALS AND METHODS}

\section{Disk plow}

The disk plow has disks inclined rearwards for additional penetration (Vozka, 2007). The angle of attachment of the disk to the direction of travel is called the disk angle (Vozka, 2007). However, the disk angle is the angle in the horizontal plane between the path of the travel and the line passing through the plane of the disk. The tilt angle of a disk plow is the slant (tilt) backward of the disk from the vertical (Bukhari et al., 1992).

\section{Field experiments and fuel consumption measurements}

The field experiments were carried out at special farm located in Riyadh, Saudi Arabia. The coordinators were longitude of $47.1^{\circ} \mathrm{E}$ and latitude of $24.33^{\circ} \mathrm{N}$. The purpose of the field experiments was to determine fuel consumption of a disk plow as affected by five factors, namely: plowing speed, plowing depth, disk angle, tilt angle and soil moisture content. The soil in the experimental site was loamy sand (sand 
percentage was $80.22 \%$, silt percentage was $14.57 \%$ and clay percentage was $5.21 \%$ ). Additionally, average soil bulk density was $1.52 \mathrm{~g} / \mathrm{cm}^{3}$.

The disk plow (Nardi, mounted category II, weight 362 kg, Italy), model MF 38, serial No. TDPE48/D was utilized in the field experiments. It had three disks with 66 $\mathrm{cm}$ disk diameter and the distance between the disks was $60 \mathrm{~cm}$ (Fig. 1). The disk plow was hitched to New Holland tractor model 100-90 (power $=74.57 \mathrm{~kW}$ ). Three levels of the investigated factors were considered. However, plowing speeds were obtained by changing tractor gear box gears. Also, soil moisture content was adjusted by centre pivot irrigation.

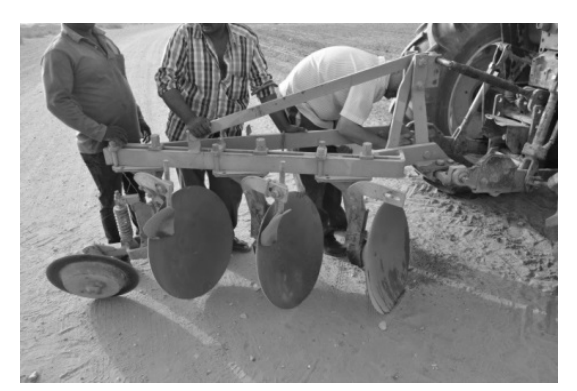

Fig. 1. Adjusting level of the used mounted disk plow.

An experimental block of $30 \mathrm{~m}$ long by $2 \mathrm{~m}$ wide was used for each treatment. A small block of approximately $10 \mathrm{~m}$ long by $2 \mathrm{~m}$ wide in the beginning of each tested block was used to enable the tractor and the disk plow to reach the required plowing speed and plowing depth. The depth of cut was measured with a steel tape from the bottom of the furrow to the surface level of the soil at eleven randomly selected places.

Fuel consumption rate for each treatment was measured by starting plowing the plot with full tank capacity. After finishing plowing one strip, the fuel tank was refilled with a graduated cylinder and the amount of fuel used for refilling the tank was recorded and the time taken to finish a specific strip was also recorded. The consumed fuel quantity was divided on the consumed time to get the fuel consumption rate in lit/h. Field experiments were performed using different levels of factors as seen in Table (1).

Table 1. Investigated factors and their levels.

\begin{tabular}{|l|c|c|c|}
\hline \multirow{2}{*}{ Independent factors (unit) } & \multicolumn{2}{|l|}{ Levels } & 0 \\
\cline { 2 - 4 } & -1 & 4 & +1 \\
\hline Plowing speed $(\mathrm{X} 1, \mathrm{~km} / \mathrm{h})$ & 3 & 15 & 20 \\
\hline Plowing depth $(\mathrm{X} 2, \mathrm{~cm})$ & 10 & 45 & 50 \\
\hline Disk angle $\left(\mathrm{X} 3^{\circ}\right)$ & 40 & 20 & 25 \\
\hline Tilt angle $\left(\mathrm{X}{ }^{\circ}\right)$ & 15 & 9 & 12 \\
\hline Soil moisture content $(\mathrm{X} 5, \% \mathrm{db})$ & 6 & 9 \\
\hline
\end{tabular}


The factors listed in Table (1) were then applied into MINITAB software Version 16 whereby half factorial Central Composite Design (CCD) was employed to obtain the experimental design as shown in Table (2). According to half $2^{5}$ factorial design, there is at least 32 experiments as seen in Table (2). If a researcher decides to provide experiments in 3 replications, it means more experiments. Although more than one replication may produce more powerful results (Gençosman et al., 2012), in this study, as each experiment takes time and effort, only one replication was chosen. The data collection for the fuel consumption was achieved according to the experimental design as shown in Table (2).

Table 2. Experimental design recommended by MINITAB software Version 16.

\begin{tabular}{|c|c|c|c|c|c|}
\hline No. & $\begin{array}{l}\text { Plowing speed } \\
\text { (X1) }\end{array}$ & $\begin{array}{l}\text { Plowing depth } \\
\text { (X2) }\end{array}$ & Disk angle (X3) & $\begin{array}{c}\text { Tilt angle } \\
\text { (X4) }\end{array}$ & $\begin{array}{l}\text { Soil moisture content } \\
\text { (X5) }\end{array}$ \\
\hline & $(\mathrm{km} / \mathrm{h})$ & $(\mathrm{cm})$ & $\left({ }^{\circ}\right)$ & $\left({ }^{\circ}\right)$ & (\%db) \\
\hline 1 & 5 & 20 & 40 & 15 & 12 \\
\hline 2 & 4 & 15 & 45 & 20 & 9 \\
\hline 3 & 4 & 15 & 45 & 20 & 6 \\
\hline 4 & 3 & 10 & 50 & 15 & 6 \\
\hline 5 & 4 & 15 & 45 & 20 & 9 \\
\hline 6 & 3 & 20 & 40 & 15 & 6 \\
\hline 7 & 4 & 15 & 45 & 15 & 9 \\
\hline 8 & 4 & 20 & 45 & 20 & 9 \\
\hline 9 & 3 & 20 & 50 & 15 & 12 \\
\hline 10 & 4 & 15 & 45 & 20 & 9 \\
\hline 11 & 5 & 10 & 50 & 25 & 6 \\
\hline 12 & 4 & 15 & 45 & 20 & 9 \\
\hline 13 & 4 & 15 & 40 & 20 & 9 \\
\hline 14 & 3 & 10 & 40 & 25 & 6 \\
\hline 15 & 4 & 10 & 45 & 20 & 9 \\
\hline 16 & 5 & 20 & 50 & 15 & 6 \\
\hline 17 & 4 & 15 & 45 & 20 & 9 \\
\hline 18 & 5 & 10 & 50 & 15 & 12 \\
\hline 19 & 3 & 20 & 50 & 25 & 6 \\
\hline 20 & 4 & 15 & 45 & 20 & 12 \\
\hline 21 & 4 & 15 & 45 & 20 & 9 \\
\hline 22 & 5 & 10 & 40 & 25 & 12 \\
\hline 23 & 3 & 10 & 50 & 25 & 12 \\
\hline 24 & 5 & 10 & 40 & 15 & 6 \\
\hline 25 & 5 & 15 & 45 & 20 & 9 \\
\hline 26 & 4 & 15 & 50 & 20 & 9 \\
\hline 27 & 3 & 20 & 40 & 25 & 12 \\
\hline 28 & 5 & 20 & 50 & 25 & 12 \\
\hline 29 & 3 & 10 & 40 & 15 & 12 \\
\hline 30 & 3 & 15 & 45 & 20 & 9 \\
\hline 31 & 4 & 15 & 45 & 25 & 9 \\
\hline 32 & 5 & 20 & 40 & 25 & 6 \\
\hline
\end{tabular}




\section{Data analysis}

Response surface regression analysis was performed to obtain a second-order polynomial equation or model. Statistical analysis of the model was represented in the form of Analysis of Variance (ANOVA). The MINITAB software Version 16 was also used for optimization analysis.

\section{RESULTS AND DISCUSSION}

\section{Model fitting}

Results in Table (3) show that the actual and predicted fuel consumption. The lowest actual and predicted fuel consumption were $3.28 \mathrm{lit} / \mathrm{h}$ and $2.47 \mathrm{lit} / \mathrm{h}$, respectively. The lowest actual fuel consumption was at factors whereby plowing speed was $3 \mathrm{~km} / \mathrm{h}$, plowing depth was $10 \mathrm{~cm}$, disk angle was $50^{\circ}$, tilt angle was $25^{\circ}$ and soil moisture content was $12 \% \mathrm{db}$. Meanwhile, the lowest predicted fuel consumption was at factors whereby plowing speed was $3 \mathrm{~km} / \mathrm{h}$, plowing depth was $15 \mathrm{~cm}$, disk angle was $45^{\circ}$, tilt angle was $20^{\circ}$ and soil moisture content was $9 \% \mathrm{db}$.

Table 3. Factors and comparison between response (fuel consumption) actual and predicted.

\begin{tabular}{|c|c|c|c|c|c|c|c|}
\hline \multirow[t]{3}{*}{ No. } & \multicolumn{5}{|c|}{ Factors } & \multicolumn{2}{|c|}{ Fuel consumption } \\
\hline & $\mathrm{X} 1$ & $\mathrm{X} 2$ & $\mathrm{X3}$ & $\mathrm{X} 4$ & $\times 5$ & Actual & Predicted \\
\hline & $(\mathrm{km} / \mathrm{h})$ & $(\mathrm{cm})$ & $\left({ }^{\circ}\right)$ & $\left({ }^{\circ}\right)$ & (\%db) & (lit/h) & (lit/h) \\
\hline 1 & 5 & 20 & 40 & 15 & 12 & 9.63 & 9.6976 \\
\hline 2 & 4 & 15 & 45 & 20 & 9 & 4.92 & 5.0397 \\
\hline 3 & 4 & 15 & 45 & 20 & 6 & 4.26 & 4.5002 \\
\hline 4 & 3 & 10 & 50 & 15 & 6 & 5.30 & 4.9426 \\
\hline 5 & 4 & 15 & 45 & 20 & 9 & 4.64 & 5.0397 \\
\hline 6 & 3 & 20 & 40 & 15 & 6 & 3.69 & 3.8490 \\
\hline 7 & 4 & 15 & 45 & 15 & 9 & 4.24 & 5.3991 \\
\hline 8 & 4 & 20 & 45 & 20 & 9 & 5.52 & 4.6347 \\
\hline 9 & 3 & 20 & 50 & 15 & 12 & 3.71 & 3.6340 \\
\hline 10 & 4 & 15 & 45 & 20 & 9 & 4.69 & 5.0397 \\
\hline 11 & 5 & 10 & 50 & 25 & 6 & 8.57 & 8.3509 \\
\hline 12 & 4 & 15 & 45 & 20 & 9 & 4.60 & 5.0397 \\
\hline 13 & 4 & 15 & 40 & 20 & 9 & 9.28 & 7.6902 \\
\hline 14 & 3 & 10 & 40 & 25 & 6 & 8.03 & 8.3598 \\
\hline 15 & 4 & 10 & 45 & 20 & 9 & 4.29 & 4.7658 \\
\hline 16 & 5 & 20 & 50 & 15 & 6 & 8.36 & 7.9701 \\
\hline 17 & 4 & 15 & 45 & 20 & 9 & 4.87 & 5.0397 \\
\hline 18 & 5 & 10 & 50 & 15 & 12 & 12.24 & 11.7912 \\
\hline 19 & 3 & 20 & 50 & 25 & 6 & 3.37 & 3.5237 \\
\hline 20 & 4 & 15 & 45 & 20 & 12 & 6.12 & 5.4702 \\
\hline 21 & 4 & 15 & 45 & 20 & 9 & 4.88 & 5.0397 \\
\hline 22 & 5 & 10 & 40 & 25 & 12 & 13.24 & 13.4784 \\
\hline 23 & 3 & 10 & 50 & 25 & 12 & 3.28 & 3.3748 \\
\hline 24 & 5 & 10 & 40 & 15 & 6 & 6.24 & 6.0262 \\
\hline 25 & 5 & 15 & 45 & 20 & 9 & 6.55 & 7.1558 \\
\hline 26 & 4 & 15 & 50 & 20 & 9 & 4.58 & 5.7602 \\
\hline 27 & 3 & 20 & 40 & 25 & 12 & 8.78 & 9.3912 \\
\hline 28 & 5 & 20 & 50 & 25 & 12 & 8.25 & 8.3123 \\
\hline 29 & 3 & 10 & 40 & 15 & 12 & 3.72 & 3.8201 \\
\hline 30 & 3 & 15 & 45 & 20 & 9 & 3.49 & 2.4747 \\
\hline 31 & 4 & 15 & 45 & 25 & 9 & 8.94 & 7.3714 \\
\hline 32 & 5 & 20 & 40 & 25 & 6 & 12.42 & 12.7173 \\
\hline
\end{tabular}


Response surface regression analysis was performed and results of estimated regression coefficients of second-order polynomial model for optimizing fuel consumption are as shown in Table (4). Based on the results in Table (4), the secondorder polynomial model equation for optimizing fuel consumption of a disk plow operating in loamy sand soil is as given in equation (1):

$$
\begin{aligned}
& Y=84.4618+0.4231 X 1+1.425 X 2-4.7652 X 3+1.051 X 4+0.6249 X 5-0.2236 X 1 X 1- \\
& 0.0136 \times 2 \times 2+0.0674 \times 3 \times 3+0.0538 \times 4 \times 4-0.006 \times 5 \times 5-0.0107 \times 1 \times 2+ \\
& 0.0556 \times 1 \times 3-0.0129 \times 1 \times 4+0.1806 \times 1 \times 5-0.0225 \times 2 \times 3+0.0045 \times 2 \times 4- \\
& 0.0075 \times 2 \times 5-0.0633 \times 3 \times 4-0.013 \times 3 \times 5-0.0190 \times 4 \times 5
\end{aligned}
$$

Where: $\mathrm{X} 1=$ plowing speed $(\mathrm{km} / \mathrm{h}), \mathrm{X} 2=$ plowing depth $(\mathrm{cm}), \mathrm{X} 3=$ disk angle $\left({ }^{\circ}\right), \mathrm{X} 4$ $=$ tilt angle $\left({ }^{\circ}\right)$ and $X 5=$ soil moisture content $(\% \mathrm{db})$. The significant second-order polynomial model equation at the $5 \%$ level for the optimization of fuel consumption of

\begin{tabular}{|c|c|c|c|c|}
\hline Term & Regression coefficients & SE Coefficient & $\mathrm{T}$ & $\mathrm{P}$ \\
\hline Constant & 84.4618 & 51.2966 & 1.647 & 0.128 \\
\hline $\mathrm{X} 1$ & 0.4231 & 6.1363 & 0.069 & 0.946 \\
\hline $\mathrm{X} 2$ & 1.4250 & 1.0053 & 1.418 & 0.184 \\
\hline $\mathrm{X} 3$ & -4.7652 & 2.4715 & -1.928 & 0.08 \\
\hline $\mathrm{X} 4$ & 1.0510 & 1.2273 & 0.856 & 0.41 \\
\hline $\mathrm{X} 5$ & 0.6249 & 1.6755 & 0.373 & 0.716 \\
\hline $\mathrm{X} 1 \mathrm{X} 1$ & -0.2236 & 0.6784 & -0.330 & 0.748 \\
\hline$\times 2 \times 2$ & -0.0136 & 0.6784 & -0.499 & 0.627 \\
\hline$\times 3 \times 3$ & 0.0674 & 0.0271 & 2.486 & 0.03 \\
\hline $\mathrm{X} 4 \mathrm{X} 4$ & 0.0538 & 0.0271 & 1.982 & 0.073 \\
\hline$\times 5 \times 5$ & -0.0060 & 0.0271 & -0.08 & 0.938 \\
\hline $\mathrm{X} 1 \mathrm{X} 2$ & -0.0107 & 0.0754 & -0.201 & 0.844 \\
\hline $\mathrm{X} 1 \mathrm{X} 3$ & 0.0556 & 0.0532 & 1.044 & 0.319 \\
\hline $\mathrm{X} 1 \mathrm{X} 4$ & -0.0129 & 0.0532 & -0.243 & 0.813 \\
\hline $\mathrm{X} 1 \mathrm{X} 5$ & 0.1806 & 0.0532 & 2.036 & 0.067 \\
\hline$\times 2 \times 3$ & -0.0225 & 0.0887 & -2.111 & 0.058 \\
\hline $\mathrm{X} 2 \times 4$ & 0.0045 & 0.0106 & 0.424 & 0.68 \\
\hline$\times 2 \times 5$ & -0.0075 & 0.0177 & -0.425 & 0.679 \\
\hline$\times 3 \times 4$ & -0.0633 & 0.0106 & -5.951 & 0.000 \\
\hline$\times 3 \times 5$ & -0.0130 & 0.0177 & -0.732 & 0.48 \\
\hline$\times 4 \times 5$ & -0.0190 & 0.0177 & -1.072 & 0.306 \\
\hline \multicolumn{2}{|c|}{$R^{2}=94.94 \%$} & \multicolumn{2}{|c|}{$\mathrm{R}^{2}$ (adjusted) $=85.79 \%$} & \\
\hline
\end{tabular}
a disk plow operating in loamy sand soil is same as in Eq. (1).

Table 4. Estimated regression coefficients of second-order polynomial model for optimizing fuel consumption of a disk plow operating in loamy sand soil.

$\mathrm{SE}=$ standard error, $\mathrm{T}=$ student test, $\mathrm{P}=$ probability .

By referring to Table (4), it was found that the linear factor of disk angle (X3) showed negative coefficient and similar result was seen by Ismail (2002), who reported that increasing disk angel decreased the draft requirements until the disk angle equal to $43^{\circ}$ then the draft was increased. Meanwhile, linear factors of plowing speed (X1), plowing depth (X2), tilt angle (X4) and soil moisture content (X5) showed 
positive coefficients. Square factors such as disk angle (X3X3) and tilt angle (X4X4) showed positive coefficients. Meanwhile, square factors of plowing speed (X1X1), plowing depth (X2X2) and soil moisture content (X5X5) showed negative coefficients. Quadratic or interaction factors of plowing speed and disk angle (X1X3), plowing speed and soil moisture content (X1X5) and plowing depth and tilt angle (X2X4) showed positive coefficients. Meanwhile, interaction factors of plowing speed and plowing depth (X1X2), plowing speed and tilt angle (X1X4), plowing depth and disk angle (X2X3), plowing depth and soil moisture content (X2X5), disk angle and tilt angle (X3X4), disk angle and soil moisture content (X3X5) and tilt angle and soil moisture content (X4X5) showed negative coefficients.

Student $T$ test was used to determine the significance of the estimated coefficients of the regression model equation (Eq.1). The student $T$ test value can be obtained by dividing each coefficient by its standard error (Mullai et al., 2010). However, $\mathrm{P}$ values were used as a tool to evaluate the significance and contribution of each factor (Thanapimmetha et al., 2011). The present study showed that square factor (X3X3) and interaction factor (X3X4) terms were highly significant.

\section{Model validation}

The goodness of fit of the regression model was determined by coefficient of determination $\left(R^{2}\right)$ which provides a measure of how much variability in the observed response values can be explained by the experimental factors and their interactions. Results in Table (4) showed that $R^{2}$ value was $94.96 \%$ which signified $94.96 \%$ of the variability in the observed response values could be explained by the model while only $5.04 \%$ of the variability in the observed response values cannot be explained by the model. The remaining $\mathrm{R}^{2}$ value of $5.04 \%$ of the total variations may be attributed to other factors like skills of the operator (Leghari et al., 2016) which were not included in the model. The adjusted $R^{2}$ was a corrected value for $R^{2}$ after the elimination of unnecessary model terms. The adjusted $R^{2}$ would be remarkably smaller than the $R^{2}$ if there were many non-significant terms have been included in the model (Fang et al., 2010). In this study, it was found that the adjusted $R^{2}$ was $85.79 \%$. The high adjusted $R^{2}$ value was attributed to the absence of non-significant terms in the model. The high adjusted $R^{2}$ and $R^{2}$ values thus, indicated a high dependence and correlation between the observed and predicted value responses.

ANOVA was performed to test for the significance and adequacy of the secondorder polynomial model. The results are as summarized in Table (5). The significance of regression was evaluated by $\mathrm{F}$ and $\mathrm{P}$ values using Fischer's and null-hypothesis tests. The regression model found in this study was highly significant as denoted by 
the $F$ and $P$ values with 10.36 and 0.000 , respectively. The square and quadratic factors were highly significant as denoted by $F$ values of 7.75 and 4.72 , respectively and $P$ values of 0.002 and 0.009 , respectively.

Lack of fit test was also performed. It describes the variation in the data around the fitted model (Noordin et al., 2004). Patel et al. (2011) testified that insignificant lack of fit indicates a good model. However, insignificant lack of fit is desired as significant lack of fit indicates that there might be contributions in the regressesresponse relationship that are not accounted for by the model. Principally, the lack of fit describes the variation in the data to the fitted model. In the case that the model does not fit the data sufficiently, the lack of fit will be significant. The F value for the lack of fit can be obtained by dividing the lack of fit mean square by its pure error mean square. Results of the lack of fit are shown in Table (5) and it was found that the $F$ and $P$ values for the lack of fit were 106.12 and 0.000 , respectively. The significant $P$ value thus indicates there might be contributions in the regressesresponse relationship that are not accounted for by the model like cubic terms. In application of response surface methodology for optimization of picker-husker harvesting losses in corn seed, Pishgar-Komleh (2012) found that there was a significant difference $(P<0.05)$ lack of fit for obtained linear model, so in order to appraise the adequacy of the fitted model several indicators were used. Swain et al. (2014) found that the lack of fit was significant and $R^{2}$ values were low for modeling drying rate and drying efficiency, indicating that a high proportion of the variability was not explained by the data.

\section{Optimization analysis}

Response optimizer was performed and the result at optimum conditions for the lowest fuel consumption is shown in Fig. (2). Results of optimum conditions for the lowest fuel consumption obtained from response optimizer of MINITAB software Version 16 were occurred at plowing speed of $3.24 \mathrm{~km} / \mathrm{h}$, plowing depth of $10.03 \mathrm{~cm}$, disk angle of $40^{\circ}$, tilt angle of $15^{\circ}$ and soil moisture content of $6.06 \% \mathrm{db}$. The difference between the verification and predicted values of the fuel consumption was less than $5 \%$, therefore, the optimum conditions for the fuel consumption predicted by MINITAB software Version 16 could be accepted. The surface plots for all pairs of investigated factors are illustrated in Fig. (3) and Fig. (4). As example, from Fig. (4), it is clear that the fuel consumption increased at increasing of plowing speed (X1) and plowing depth (X2). The positive effect of both the independent factors suggested higher fuel consumption at a higher level of these factors. 
Table 5. ANOVA for optimization of fuel consumption of a disk plow operating in loamy sand soil.

\begin{tabular}{|c|c|c|c|c|c|c|}
\hline Source & DF & Squared SS & $\begin{array}{c}\text { Adjusted } \\
\text { SS }\end{array}$ & Adjusted MS & F & P \\
\hline Regression & 20 & 234.581 & 234.581 & 11.72905 & 10.36 & 0.000 \\
\hline Linear & 5 & 137.201 & 6.528 & 1.3056 & 1.15 & 0.39 \\
\hline X1 & 1 & 98.614 & 0.005 & 0.005 & 0.00 & 0.946 \\
\hline X2 & 1 & 0.076 & 2.275 & 2.275 & 2.01 & 0.184 \\
\hline X3 & 1 & 16.777 & 4.21 & 4.21 & 3.72 & 0.08 \\
\hline X4 & 1 & 17.492 & 0.83 & 0.83 & 0.73 & 0.41 \\
\hline X5 & 1 & 4.242 & 0.158 & 0.158 & 0.14 & 0.716 \\
\hline Square & 5 & 43.874 & 43.874 & 8.7748 & 7.75 & 0.002 \\
\hline X1X1 & 1 & 23.957 & 0.123 & 0.123 & 0.11 & 0.748 \\
\hline X2X2 & 1 & 3.039 & 0.283 & 0.283 & 0.25 & 0.627 \\
\hline X3X3 & 1 & 12.26 & 6.996 & 6.996 & 6.18 & 0.03 \\
\hline X4X4 & 1 & 4.61 & 4.447 & 4.447 & 3.93 & 0.073 \\
\hline X5X5 & 1 & 0.007 & 0.007 & 0.007 & 0.01 & 0.938 \\
\hline Interaction & 10 & 53.506 & 53.506 & 5.3506 & 4.72 & 0.009 \\
\hline X1X2 & 1 & 0.046 & 0.046 & 0.046 & 0.04 & 0.844 \\
\hline X1X3 & 1 & 1.235 & 1.235 & 1.235 & 1.09 & 0.319 \\
\hline X1X4 & 1 & 0.067 & 0.067 & 0.067 & 0.06 & 0.813 \\
\hline X1X5 & 1 & 4.695 & 4.695 & 4.695 & 4.15 & 0.067 \\
\hline X2X3 & 1 & 5.047 & 5.047 & 5.047 & 4.46 & 0.058 \\
\hline X2X4 & 1 & 0.203 & 0.203 & 0.203 & 0.18 & 0.68 \\
\hline X2X5 & 1 & 0.205 & 0.205 & 0.205 & 0.18 & 0.679 \\
\hline X3X4 & 1 & 40.1 & 40.1 & 40.1 & 35.41 & 0.000 \\
\hline X3X5 & 1 & 0.606 & 0.606 & 0.606 & 0.51 & 0.48 \\
\hline X4X5 & 1 & 1.302 & 1.302 & 1.302 & 1.15 & 0.306 \\
\hline Residual Error & 11 & 12.457 & 12.457 & 1.132455 & & \\
\hline Lack of fit & 6 & 12.360 & 12.36 & 2.06 & 106.12 & 0.000 \\
\hline Pure error & 5 & 0.097 & 0.097 & 0.0194 & & \\
\hline Total & 31 & 247.038 & & & & \\
\hline & & & & & & \\
\hline & & & & & \\
\hline
\end{tabular}




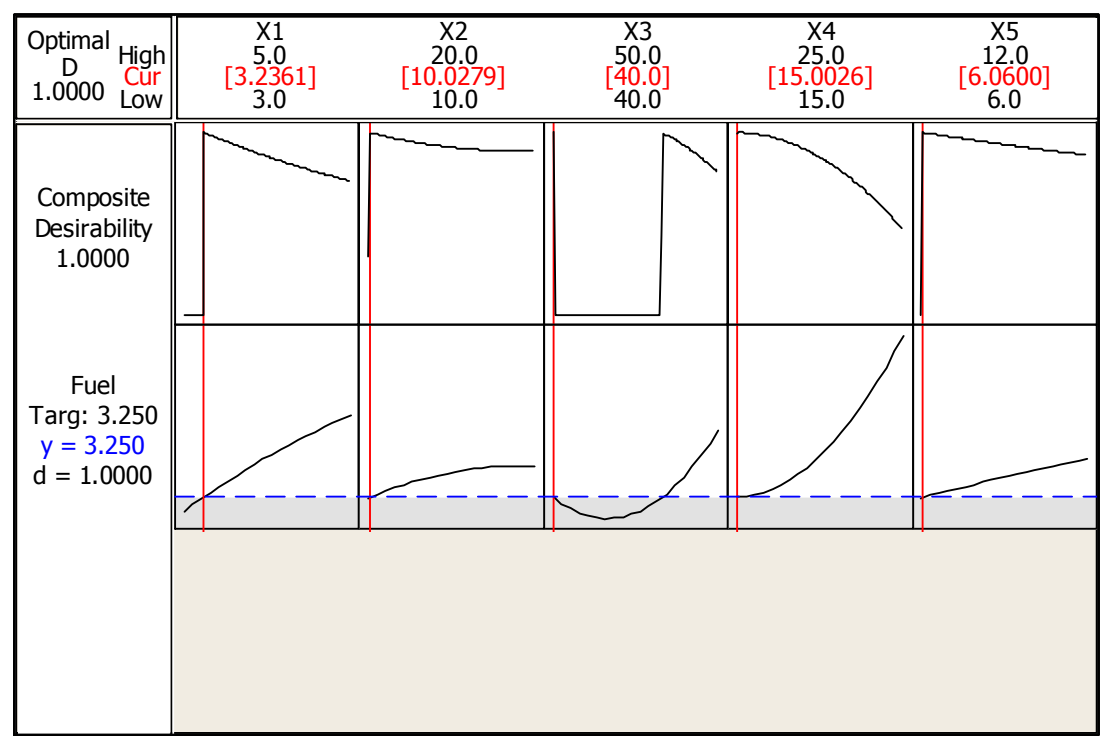

Fig. 2. Response optimizer at optimum conditions for lower fuel consumption.
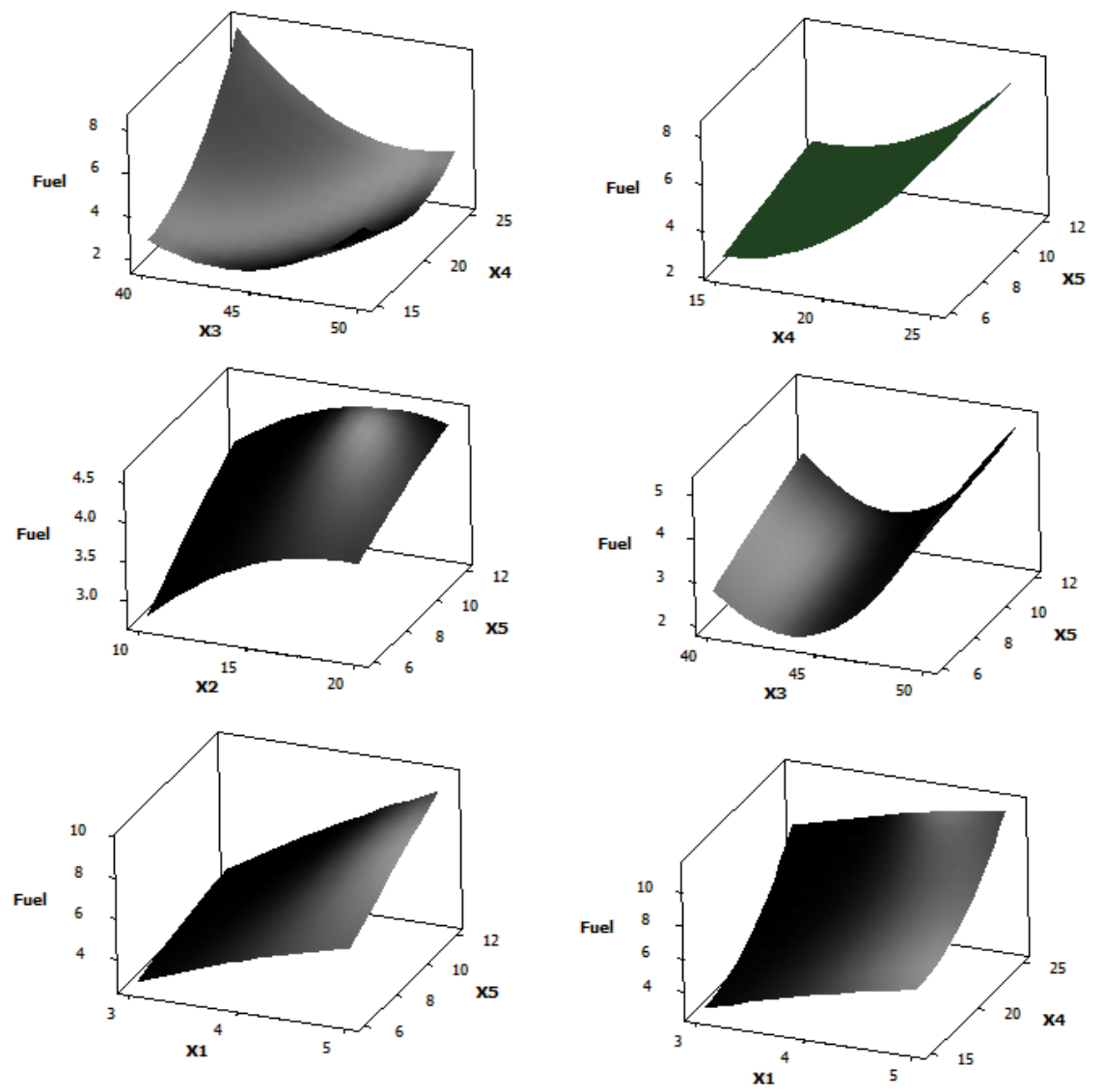

Fig. 3. The surface plots for two pairs of investigated factors $(\mathrm{X} 1, \mathrm{X} 5 ; \mathrm{X} 1, \mathrm{X} 4 ; \mathrm{X} 2, \mathrm{X} 5 ; \mathrm{X} 3, \mathrm{X} 5 ; \mathrm{X} 3, \mathrm{X} 4 ; \mathrm{X} 4, \mathrm{X} 5)$ : Fuel in lit/h. 

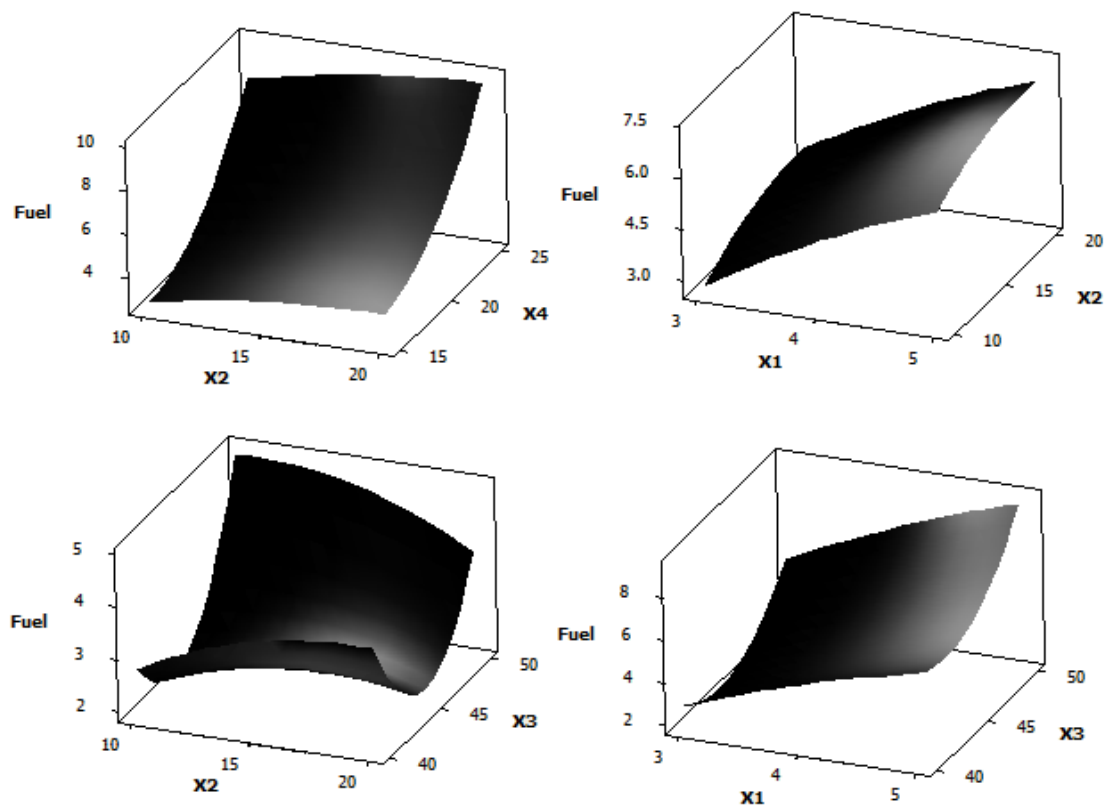

Fig. 4. The surface plots for two pairs of investigated factors $(X 2, X 4 ; X 2, X 3 ; X 1, X 3$; $\mathrm{X} 1, \mathrm{X} 2)$ : Fuel in lit/h.

\section{CONCLUSION}

The coefficient of determination $\left(R^{2}\right)$ of $94.96 \%$ was high, thus the experimental data was acceptable. Optimum conditions for the lowest fuel consumption of a disk plow operating in loamy sand soil using response surface methodology had been determined. It was found that lower fuel consumption could be optimized to be $3.25 \mathrm{lit} / \mathrm{h}$ at the optimum conditions at plowing speed of 3.24 $\mathrm{km} / \mathrm{h}$, plowing depth of $10.03 \mathrm{~cm}$, disk angle of $40^{\circ}$, tilt angle of $15^{\circ}$ and soil moisture content of $6.06 \% \mathrm{db}$. It was also found that the difference between the actual and predicted values of the fuel consumption was less than $5 \%$, therefore, the optimum conditions for the fuel consumption predicted by MINITAB Software Version 16 could be accepted.

\section{REFERENCES}

1. Abdalla, O.A., E. A. Mohamed, A. M. El Naim, M. A. El Shiekh and M. B. Zaied. 2014. Effect of disc and tilt angles of disc plough on tractor performance under clay soil. Current Research in Agricultural Sciences, 1(3): 83-94.

2. Bukhari, S., G.R. Mari, M. Zafaruhah, J.M. Baloch and M.S. Panhwar. 1992. Effect of disk and tilt angle on field capacity and power requirements of 
mounted plow. Agricultural Mechanization in Asia, Africa, and Latin America, 23(2):9-13.

3. Fang, X.L., J.T. Feng, W.G. Zhang, Y.H. Wang and X. Zhang. 2010. Optimization of growth medium and fermentation conditions for improved antibiotic activity of Xenorhabdus nematophila TB using a statistical approach. African Journal of Biotechnology, 9:8068-8077.

4. Gençosman, B. C., A.Y. Orbak and I. Orbak. 2012. Factor analysis and response surface optimization for copper removal from aqueous solutions. Proceedings of the 2012 International Conference on Industrial Engineering and Operations Management Istanbul, Turkey,:1286-1291.

5. Ismail, K.M. 2002. Statistical treatment of disk tool data for predicting soil draft. Misr J. Ag. Eng., 19(2):455-466.

6. Kepner, R.A., R. Bainer and E.L. Barger. 1972. Principles of farm machinery. The AVI Publishing Company, Inc., second edition, ch7:153-169.

7. Koocheki, A., A.R. Taherian, S. M.A. Razavi and A. Bostan. 2009. Response surface methodology for optimization of extraction yield, viscosity, hue and emulsion stability of mucilage extracted from Lepidium perfoliatum seeds. Food Hydrocolloids, 23:2369-2379.

8. Leghari, N., V. K. Oad, A. A. Shaikh and A. A. Soomro. 2016. Analysis of different tillage implements with respect to reduced fuel consumption, tractor operating speed and its wheel slippage. Sindh Univ. Res. Jour. (Sci. Ser.), 48 (1):37-40.

9. Mamkag, A.M. 2002. The effect of forward speed, disc and tilt angle on fuel consumption using disc plow. Iraq Journal of Agricultural Sciences, 3(4):100104.

10. Mullai, P.N., F. S. Ali and R.R. Eldon. 2010. Statistical analysis of main and interaction effects to optimize xylanase production under submerged cultivation conditions. Journal of Agricultural Science, 2:144-153.

11. Namdari, M., S. Rafiee and A. Jafari. 2011. FMEA method to optimize fuel consumption in tillage by moldboard plow. International Journal of Applied Engineering Research, Dindigul, 1 (4):734-742.

12. Noordin, M.Y., V.C. Venkatesh and A. Abdullah. 2004. Application of response surface methodology in describing the performance of coated carbide tools when turning AISI 1045 steel. Journal of Materials Processing Technology, 145:46-58. 
13. Osman, A.N., L. Xia and Z. DongXing. 2011. Effects of tilt angle of disk plow on some soil physical properties, work rate and wheel slippage under light clay soil. International J. of Agricultural and Biological Engineering, 4(2):29-35.

14. Patel, S., D. Kothari and A. Goyal. 2011. Enhancement of dextransucrase activity of Pediococcus pentosaceus SPAm1 by Response Surface Methodology. Indian Journal of Biotechnology, 10: 346-351.

15. Pishgar-Komleh, S.H., A. Keyhani, M.R. Mostofi-Sarkari and A. Jafari. 2012. Application of response surface methodology for optimization of picker-husker harvesting losses in corn seed. Iranica Journal of Energy \& Environment, 3 (2):134-142.

16. Swain, S., D.V.K. Samuel, A. Kar, L.M. Bal and G.P. Sahoo. 2014. Optimization of colour parameters and drying efficiency in osmotically pretreated microwave assisted drying of yellow sweet pepper (Capsicum annum L.) using ResponseSurface Methodology. Journal of Food Research and Technology, 2(2):67-76.

17. Thanapimmetha, A., K. Vuttibunchon, M. Saisriyoot and P. Srinophakun. 2011. Chemical and microbial hydrolysis of sweet sorghum bagasse for ethanol production. World Renewable Energy Congress-Sweden, Linköping, Sweden., 1:389-396.

18. Vozka, P. 2007. Comparison of alternative tillage systems. MSc Thesis, School of Applied Sciences, National Soil Resources Institute, Cranfield University, Uk,110.

19. Zugec, I., B. Stipesevic and I. Kelava. 2000. Rational soil tillage for cereals (Winter Wheat-Triticum Aestivum L. and Spring Barley-Hordeum Vulgare L. in eastern Croatia. In: Proceedings of the 15th ISTRO Conference. Fort Worth, USA. 


\section{تطبيق طريقة استجابة السطح لأمثلة استهلاك الوقود \\ لمحراث قلاب قرصي في تربة لومية رملية}

\section{عبد الواحد محمد أبوكريمة}

$$
\text { معهد بحوث الهندسة الزراعية، مركز البحوث الزراعية }
$$

يعتبر المحر اث القرص أداة فعالة تستخدم لقطع التربة في عمليات الحرث الابتدائي. كما تستهلك عملية الحرث كميات وقود كثثرة في عمليات الإنتاج الزر اعي، وبالتالي فإن إدارة التشغيل

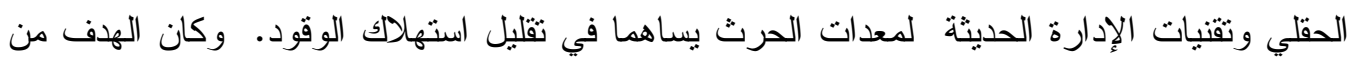

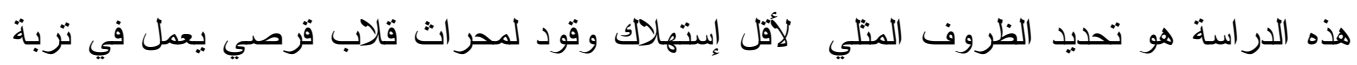

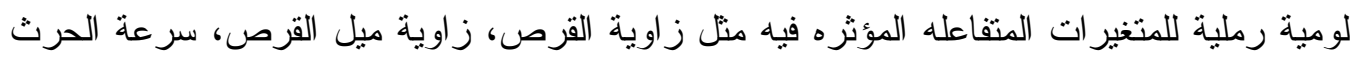
و عمق الحرث ونسبة الرطوبة في التزبة و الحصول على أنسب التفاعلات لهذه المتغير ات التي نساهم في تقليل استهلاك الوقود أثناء عملية الحرث من خلال تطبيق طريه طريقة استجابة السطح. في البداية نم

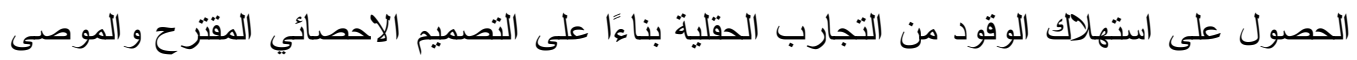

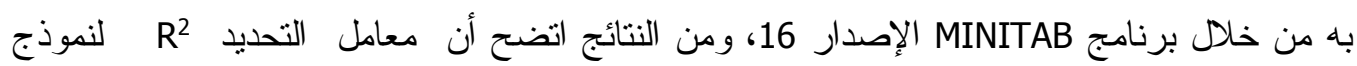
استهالك الوقود بناء على المتغير ات المدروسة كان 16، ومن 94.96 \%، مما يعني أن البيانات التجريبية

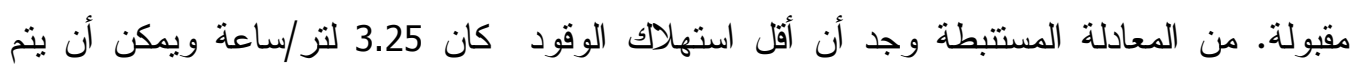
الحصول عليه عندما تكون سرعة الحرث 3.24 كم/ساعة، وعمق الحرث 10.03 سم، وزاوية القرص 40، وزاوية الميل للقرص 15 م والمحتوى الرطوبي للتربة 6.06\% على أساس جاف.

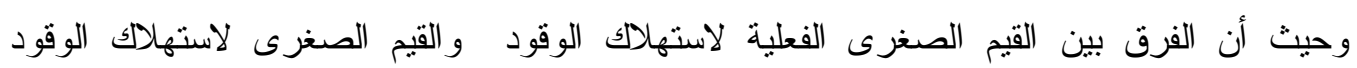
المتوقعه عند الظروف المنلى أقل من 5\%، لذا يمكن استخدام النموذج المطور لتقدير استهلاك الوقود لإد لمحر اث قلاب قرصي يعمل في تربة لومية رملية ضمن حدود متغير ات التجربة. 